of Europe. To Professor Volta was reserved the merit of bringing his countryman's experiments to the test of sound reasoning and accurate investigation. . . ." Just at that time Europe was in the early throes of one of her periodical upheavals, and it was partly this which had led Volta to send his memoir to London.

Seven years later came a much more important paper in the form of a letter of 8,500 words in French to Sir Joseph Banks, which ultimately appeared in the Philosophical Transactions under the title "On the Electricity Excited by the Mere Contact of Conducting Substances of Different Kinds". The effect of this communication was as startling as the announcement of Röntgen's discovery of fifty years ago. The whole scientific world became agog with galvanic piles, batteries, 'crowns of cups' and so forth. For the first time electricity could be obtained in steady and continuous currents, and so was marked an era in electrical science. The fellows of the Royal Society having been. enlightened, the members of the Royal Institution, just founded, of course had to be told; but unfortunately Dr. Garnett, not long engaged as "lecturer and scientific secretary and Editor of the Journals", made a slip and ascribed the invention of the pile to the French; Rumford heard of this, and on May 29, 1800, wrote to Banks : "I knew nothing of the matter until it was too late to prevent a mistake. I have, however, insisted on its being rectified as far as it is possible in some future lecture. ..." Next day he wrote again that Dr. Gamett is perfectly ready to atone for his lapse and will make this declaration : "Having by mistake on Wednesday, in the course of my public lecture, ascribed to the French philosophers a new and important discovery relative to galvanism, which on inquiry I find belongs to Professor Volta of Milan, I feel it my duty ..."

The old records are eloquent of the enthusiasm about the new apparatus, and fifty years later J. D. Forbes wrote: "The invention of the pile may in many respects be placed on a par with that of the steam engine. The results of the former were indeed more interesting immediately to pure science, the latter to the arts of life and the needs of civilization. Yet after half a century, this distinction can hardly be drawn with severity. The rapid pace of steam is insufficient for our needs. The electric wire conveys to its destination, ere the locomotive has time to start on its journey, tidings of joy and sorrow-life and death - of victories won, and kingdoms lost."

In the last year of the dying century, Volta was at the height of his career, a conqueror of Nature. In his native land was another conqueror, Napoleon, who in June won the battle of Marengo and so became master of northern Italy. Next year the two met in Paris. On November 11, 1801, Count Rumford wrote to Sir Joseph Banks, "At the last meeting of the mathematical and physical class [of the National Institute] the First Consul came in. .. He stayed about an hour-till the meeting was over. Volta read a paper on Galvanism and explained his theory of the action of the voltaic pile or battery. ... After Volta had finished his memoir the First Consul demanded leave from the President to speak, which being granted, he proposed to the meeting to reward M. Volta with a gold medal, and to appoint a committee to confer with M. Volta on the subject of his experiments and investigations respecting galvanism, and to make such new experiments as may bid fair to lead to further discoveries. He delivered his sentiments with great perspicacity and displayed a degree of eloquence which surprised me. . . Volta eventually got his medal and also a sum of money, and was elected a member of the Institute. Later, he became a senator of the Kingdom of Lombardy and a Count, but the world of science was enriched by no more discoveries by him.

Volta continued to work quietly at Pavia until 1819, when after acting as director of the Philosophical Faculty of the University for four years, he retired to his beloved Como, where he died on March 5, 1827, at the age of eighty-two. Up to the age of forty-nine he had remained a bachelor ; then he married Teresa Pellegrini, by whom he had three sons. His grave and monument are at Como, where at the great Exhibition held in honour of his memory in 1899 a fire destroyed a great deal of his original apparatus.

One of the best recent accounts of Volta and his work is contained in illustrated articles by Mr. Frank Walker in Engineering of January 1938.

\section{CORROSION OF METALS IN SOIL}

$T$ HE corrosion of metals buried underground is a problem of very considerable importance; it is one also of great complexity. In 1922 experiments were initiated by the U.S. National Bureau of Standards to determine the effects of various soils on materials in general use for pipes buried in the ground. From time to time reports have been issued summarizing the results obtained as the work progressed; a report has now appeared dealing with an investigation begun in 1932 to study the corrosionresistance of both ferrous and non-ferrous materials and the effect of applying improved protective coatings*.

No attempt was made to obtain series of specimens differing step-wise from each other. Manufacturers were invited to submit specimens which they believed or hoped would be resistant. Hence the various samples differed in so many ways that co-ordination of the results is a matter of extreme difficulty. The authors have themselves realized this, and deal with their data in a thoroughly sound and logical manner. They give warning that the results must be interpreted with care partly in consequence of the diffi. culty of obtaining satisfactory 'repeat' results, and also because the experimental conditions were not identical with those to which pipes would probably be subjected in practice. This latter point is particularly true when protective coatings are applied, because small laboratory specimens can be more carefully coated and handled with greater care than is possible in practice. As a result, when the authors attempt to arrive at a general conclusion of importance, it is so whittled down with exceptions and provisos as to be of disappointingly limited value. Although the detailed results will be of great value to the manufacturers who supplied the materials and upon whose behalf the research was, of course, mainly carried out, it is obviously the general conclusions that will appeal most to European readers.

Fifteen different soils were chosen, including several clays and loams, peat, muck and cinders.

* Soil-Corrosion Studies, 1941 : Ferrous and Non-Ferrous CorrosionResistant Materials and Non-bituminous Coatings. By Kirk H. Logan and Melvin Romanoff. Journal of Research, Nat. Bur. Stand., 33, No. 3 (1944). 
Important factors mentioned are the texture of the soils, their retentiveness of water, $p \mathrm{H}$ values and water-soluble contents. The $p \mathrm{H}$ values of the soils chosen ranged from $2 \cdot 6$ in Rifle peat to $9 \cdot 4$ in Merced silt loam, thus covering the ambit of soils in general.

The reasons why pipes in some soils corrode more rapidly than in others have not as yet been fully determined. Soil solutions are often too weak to account directly for the observed corrosion, but the electric conductivity of soils containing soluble salts is important. Soil bacteria may also play a part. Differences of potential between various points on the surface of the material are a fruitful source of trouble; these may be due to many causes, including the presence of scale, segregations and variations in the soil itself in contact with the material in different places.

Eight cast irons were tested, including one highalloy cast iron with $2 \cdot 61$ per cent chromium and 15.0 per cent nickel. The results of exposures for two, five, seven and nine years are compared, and the superiority of the high-alloy metal demonstrated both as regards loss in weight and depth of pitting. The plain and low-alloy cast irons (c. 0.5 per cent copper) with silicon ranging from 0.95 to $2 \cdot 50$ per cent behaved very much alike.

An interesting experiment consisted in embedding two different plain cast irons in contact in very wet Docas clay, the water-soluble material of which was almost entirely sodium chloride. At first one of the cast irons was cathodic to the other; but after considerable drying of the soil a reversal took place, the cathodic metal now becoming anodic. This illustrates the importance of such factors as soil aeration and water-retentiveness, as also the difficulty of forecasting results in practice in view of seasonal variations in rainfall and drought.

For many years attempts have been made to increase the resistance of steel to corrosion by alloying with different elements such as chromium, nickel and copper. In the present research, cleaned 5 per cent chromium steel, after various periods of exposure up to nine years in ten different soils, lost less in weight than ordinary steel but was more deeply pitted. Many investigators have already directed attention to this behaviour of chromium steels under quite other conditions of corrosion. The authors attribute it to formation of a protective superficial oxide film which breaks down locally, setting up potential differences leading to localized corrosion. This is a generally accepted view. On the other hand, cleaned nickel-copper steel $(2.47$ per cent nickel, 1.08 per cent copper) proved superior to ordinary steel both as judged by loss in weight and depth of pitting, whereas the same steels exposed with adherent scale showed no advantage after four years.

Turning now to the non-ferrous metals, a useful table is given summarizing the losses in weight sustained by nine copper alloys relatively to that of tough pitch copper taken as 100. This latter metal was very resistant to corrosion, as was also red brass (14.8 per cent zinc) and copper-nickel alloy ( 5 per cent zinc, 20.0 per cent nickel). The zinc content of the brasses included in this set ranged from 14.8 to 39.6 per cent (Muntz metal), and the apparent losses in weight rose steadily with the zinc content. It is pointed out, however, that in some cases the observed losses do not accurately indicate the extent of corrosion, since part of the zinc had been removed by selective corrosion which weakened the material. The observed depth of pitting also might be misleading as in some soils dezincification occurred, the depth of which was not known. The addition of 0.08 per cent arsenic to Muntz metal did not prevent dezincification, but the authors suggest. that more arsenic might yield better results.

It was noted that, in general, soils that are severely corrosive to iron may be non-corrosive to lead, the exceptions being highly organic soils. This is attributed in part to the formation on the metal surface of insoluble salts, such as sulphate, chloride or carbonate, which protect the underlying metal from attack. Organic salts, on the other hand, are usually soluble. The addition of 5 per cent antimony did not materially improve the resistance of the lead.

Copper tubes coated with a thin layer of tin appeared to receive a temporary protection, but in the course of four years much of the tin disappeared. Reversal of potential is suggested as a cause of failure, the tin being anodic and protecting the copper just as zinc protects galvanized iron. But reversal might be caused by the presence of tin-copper alloys which are cathodic.

Experiments with lead-coated steel pipes were not encouraging; the authors doubt if a lead coat of any reasonable thickness can be satisfactory in corrosive soils. On the other hand, zinc applied by the hot-dip method to the extent of some $3 \mathrm{oz}$. per sq. ft. increased resistance to corrosion; it is concluded, however, that it would not add more than four years to the life of the pipe.

Vitreous enamel, rubber coatings, a thick moulded coating of China wood oil with mica, and a baked-on 'Bakelite' coating were each found to reduce corrosion substantially over periods of from four to nine years.

It is impossible in a brief article to do full justice to the mass of data contained in the report. The foregoing is an attempt to lay before the reader the salient features of the research.

\section{J. Newton Friend.}

\section{OBITUARY}

President Roosevelt

Not since Abraham Lincoln was assassinated at the moment of victory eighty years ago has the death of an American president shocked the world like the passing of Franklin Delano Roosevelt on April 12, at the age of sixty-three.

Over the success and achievements of the New Deal policy which Mr. Roosevelt initiated when he entered on his first term of office as president in 1933 there is still much controversy. The policy had its faults; but, comprising economies in the public service, plans for unemployment relief, public works enterprise on a large scale, and schemes for the rehabilitation of agriculture, with the accompanying National Industrial Recovery Act, which authorized the President to frame a code of regulations for each industry, and the further legislation passed during 1934 and the first part of 1935 dealing with currency, tariff, public utilities and taxation questions, and the Social Security Act in which, for the first time, the United States accepted the principle of national unemployment insurance and old-age pensions, it nevertheless was a landmark in American history.

The full extent of Mr. Roosevelt's contribution in the New Deal policy cannot perhaps be accurately assessed as yet, though the bitterness of the personal attacks on the President mode by its opponents and the determination with which he himself supported 